\title{
“All We Have Done, We Have Done for Freedom": The Creole Slave-Ship Revolt (I84I) and the Revolutionary Atlantic
}

\author{
A NITA R UPPRECH \\ School of Humanities, University of Brighton \\ Io-I I Pavilion Parade, Brighton, East Sussex BNI IRA, UK \\ E-mail: A.Rupprecht@brighton.ac.uk
}

\begin{abstract}
AвstRact: The revolt aboard the American slaving ship the Creole (i84I) was an unprecedented success. A minority of the 135 captive African Americans aboard seized the vessel as it sailed from Norfolk, Virginia, to the New Orleans slave markets. They forced the crew to sail to the Bahamas, where they claimed their freedom. Building on previous studies of the Creole, this article argues that the revolt succeeded due to the circulation of radical struggle. Condensed in collective memory, political solidarity, and active protest and resistance, this circulation breached the boundaries between land and ocean, and gave shape to the revolutionary Atlantic. These mutineers achieved their ultimate aim of freedom due to their own prior experiences of resistance, their preparedness to risk death in violent insurrection, and because they sailed into a Bahamian context in which black Atlantic cooperation from below forced the British to serve the letter of their own law.
\end{abstract}

When news of the extraordinary success of the slave revolt aboard the Creole broke in I84I, it was hailed as another Amistad. On 7 November the American slaving brig, having left Norfolk, Virginia, sailed into Nassau with 135 self-emancipated African Americans aboard. A minority of the captives had risen, killed a slaving agent, severely wounded the captain, and forced the crew to sail them into free waters, the British having abolished slavery three years earlier. ${ }^{\text {I }}$ Occurring less than three

I. Howard Jones, "The Peculiar Institution and National Honor: The Case of the Creole Slave Revolt”, Civil War History, 2 I (1975), pp. 28-33; Edward D. Jervey and C. Harold Huber, "The Creole Affair", Journal of Negro History, 65 (1980), pp. I96-2 I I; George Hendrick and Willene Hendrick, The Creole Mutiny: A Tale of a Revolt Aboard a Slave Ship (Chicago, IL, 2003); Walter Johnson, "White Lies: Human Property and Domestic Slavery Aboard the Slave Ship Creole", Atlantic Studies, 5 (2008), pp. 237-263. Depositions of the Creole's crew are published 
years after the Amistad rebellion, and two days before those Africans sailed for Sierra Leone, American slaveholders were thrown into a "great fever" at the event. ${ }^{2}$ Unlike the Amistad rebellion, which had been a strike against Caribbean slavery under Spanish rule, the Creole struck at the very heart of American slavery under American rule. More broadly, the mutiny reaffirmed for the plantocracy that the great Atlantic wave of militant black anti-slavery rebellion and resistance shaped by the American, French, and Haitian revolutions rolled on.

Virginia had already been the site of two highly planned but ultimately unsuccessful slave plots that had deeply threatened the planter class. Gabriel Prosser's Richmond plot in I 800 was betrayed before it could be enacted, but Nat Turner's, which erupted in Southampton County in I 83 I, was the bloodiest of all slave rebellions prior to the Civil War. In I 822, Denmark Vesey, who had laboured in Haiti, plotted to take Charleston, South Carolina, on Bastille Day. In I835, the enslaved rose in Bahia, Brazil. They were wearing images of Dessalines. The huge upsurge of resistance spurred the Atlantic-wide abolitionist movement to radicalize and gather pace. In the Caribbean, the Demerara Rebellion in 1823 rejuvenated the British campaigns. In Jamaica, Sam Sharpe's "Baptist War" of I 83 I-I 832 mobilized tens of thousands of the enslaved, accelerating the British decision to pass their Abolition Acts in 1833 and I 838 . On the other side of the ocean, David Walker's incendiary Appeal [...] to the Coloured Citizens of the World, published in I829, circulated widely. William Lloyd Garrison founded The Liberator two years later.

The Creole looms large within African-American history and cultural memory, where Madison Washington, leader of the insurrection, has become immortalized as one of the great slave rebel leaders. This article offers a narrative of the mutiny that reflects on how Washington and his fellow insurgents were able to overthrow shipboard authority when so many maritime slave revolts ended in failure. It argues that the insurrection was an extraordinary achievement, but that the context in which it took place - the revolutionary Atlantic - was also pivotal to its ultimate success. The rebels rose as they were sailing along a porous eastern American seaboard, already enmeshed within wider networks of communication

in Sen. Docs. No. 51, 27 th Cong., 2nd sess., I 842 , II, pp. I-46. The depositions are available too in Parliamentary Papers, I843, [485], "Class D. Correspondence with foreign powers, not parties to conventions. Giving right of search of vessels suspected of the slave trade" [hereafter $P P, \mathrm{I} 843,[485]$ ], and it is this source that has been used in the present article. For an account of the public rhetoric surrounding the event see Maggie Sale, The Slumbering Volcano: American Slave Ship Revolts and the Production of Rebellious Masculinity (Durham, NC, 1997), pp. I 20-I45.

2. Oberlin Evangelist, I2 October I842, p. 167. 
and resistance, and thus situated at the very edges of freedom. Stories of courageous slave-ship risings were circulating in American harbours when the Creole captives were forcibly embarked. Moreover, many were aware that hundreds of African Americans had claimed their freedom in the Bahamas in a variety of unexpected ways. Once the rebels had taken the ship, their liberation was secured because they sailed into an Atlantic vortex shaped by official British abolitionism from above, and by black Atlantic solidarity from below.

\section{THE VOYAGE OF THE CREOLE}

The Americans outlawed their transatlantic slave trade in 1808 . While an illegal trade continued, as the slave markets of the southern states boomed in the face of increasing demand for labour, a rapidly commercializing and legal domestic slave trade quickly developed. By i $84 \mathrm{I}$, hundreds of slaving ships had voyaged down the south-eastern coast of North America, and along the Gulf Coast to New Orleans. There was nothing unusual about the route or the routine of the Creole. ${ }^{3}$

The brig departed from Richmond, Virginia, at midnight on Monday 25 October I 84I, under the command of Captain Robert Ensor. By the time she reached open water a week later, the vessel had accumulated a "cargo" of I 35 human beings, and several hogsheads of processed tobacco. She was bound for New Orleans. The majority of the enslaved belonged to the owners of the brig, Johnson \& Eperson, but 26 were the property of Thomas McCargo, a well-known Virginian slave trader who was also aboard. The first mate was Zephaniah Gifford, an experienced mariner; his second mate was Lucius Stevens. In addition, there were ten crew, eight black servants, and four passengers aboard. Jacob Leitner, a Prussian, assisted the steward as mate. Three of the passengers were responsible for overseeing the captives. John Hewell had particular charge of the slaves of McCargo. William Merritt, as overseer, had general charge and superintendence of all the slaves aboard ship.

Even though this was a slaving voyage, it was also something of a family affair. Ensor's wife, baby daughter, and his fifteen-year-old niece were travelling with him. McCargo's young nephew, Theophilus, was also aboard to be tutored in the business of human trafficking. The presence of the children suggests that the traders were not contemplating, or did not allow themselves to contemplate, the risk of resistance. Perhaps their nerves were soothed by the fact that five insurance policies had been put

3. Robert H. Gudmestad, A Troublesome Commerce: The Transformation of the Interstate Slave Trade (Baton Rouge, LA, 2003); Adam Rothman, Slave Country: American Expansion and the Origins of the Deep South (Cambridge, MA, 2005); Steven Deyle, Carry Me Back: The Domestic Slave Trade in American Life (New York, 2005). 
in place to cover any unlikely losses, but only three of these included any mention of slave revolt.

As was usual on these domestic voyages, the enslaved were able to occupy the deck during the day. At night, however, the women and men were confined below, separated by stacks of boxed tobacco as a way of preventing intimacies that might compromise their value. These conditions meant that four men, Madison Washington, Elijah Morris, Doc Ruffin, and Ben Blacksmith, were able to consolidate their bonds of "fictive kinship", ${ }^{4}$ and collectively to map, with at least fifteen others, the spaces of the vessel and to watch and wait as shipboard routines settled down into a daily rhythm. Washington, as "head cook of the slaves" was in a unique position to assess the possibilities for mutiny. Serving meals to the captives twice a day provided a regular opportunity to identify potential allies, locate possible weapons, and watch the crew's movements.

No record exists of the process whereby the four captives planned their course of action. Nevertheless, Solomon Northup, kidnapped and transported from Richmond for sale in New Orleans only a few months before the Creole departed, described his part in plotting a shipboard revolt in his autobiography. As for the rebels aboard the Creole, Northup and his fellow conspirators were faced with the problems of knowing whom of their compatriots they could trust, and how to trigger the surprise and exact the violence necessary for a successful mutiny. They knew the uprising should begin at night, and therefore needed to find a way to avoid being locked in the hold. Northup describes how they debated these problems, and how he trial ran a potential plan by secreting himself under an upturned ship's boat at nightfall. The success of the trial determined that Northup and his fellow rebel, Arthur, would hide themselves until they were able to emerge and attack and kill the captain and mate as they slept in their bunks. ${ }^{5}$

Although the plot was not carried through, Northup's description offers an important counter to assumptions that maritime slave revolts were always spontaneous and undirected outbursts doomed by lack of leadership and planning. It is clear that rebel leaders aboard the Creole had also choreographed significant aspects of their attack carefully, including enlisting the support of at least some of the captive women to help trigger the assault, and identifying in advance a set of weapons.

4. This phrase is most often used in relation to specific bonds forged aboard transatlantic slaving vessels and carried into the Americas, though they are relevant with respect to wider maritime communities during the period. Given what transpired, they are applicable here. See Sidney W. Minz and Richard Price, The Birth of African-American Culture: An Anthropological Perspective (Boston, MA, 1992).

5. Solomon Northup, Twelve Years a Slave (New York, I855), pp. 68-72. 


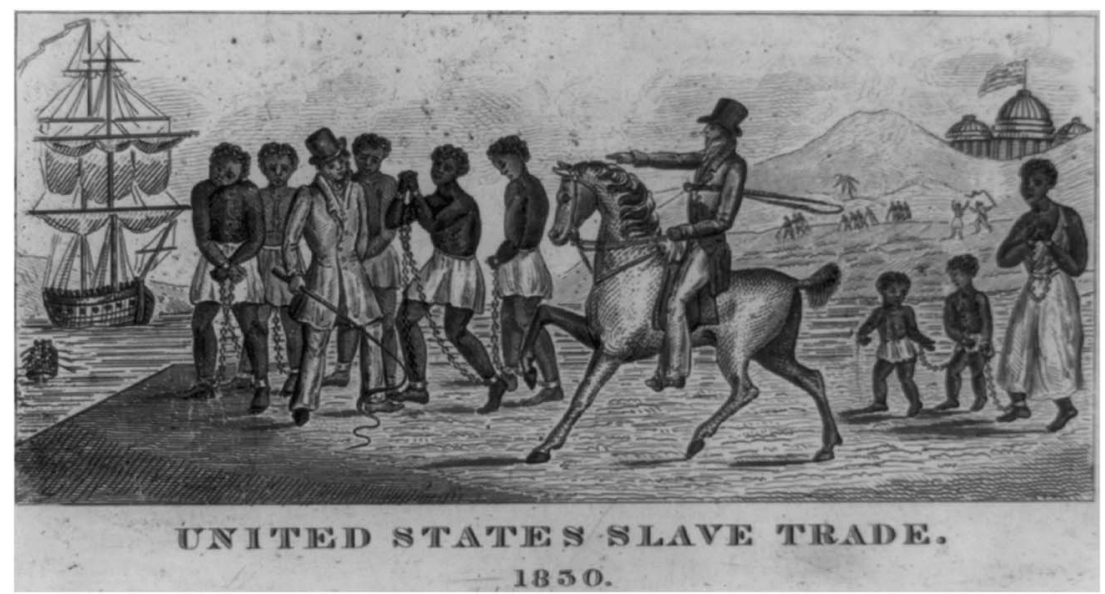

Figure I. The domestic slave trade figured prominently in American anti-slavery propaganda. The copper plate from which this image was engraved was discovered in the ruins of the Anti-Slavery Hall in Philadelphia which was burned down by anti-abolitionists in 1838 in reaction to the radicalization of the movement. The image references key elements of abolitionist iconography including the coffle, the forcible separation of families, the use of the whip, and maritime trafficking. Capitol Hill in the background signals the fact that, as the slave trade was supported legally by the Constitution, Congress had the power to outlaw the practice.

Library of Congress Prints and Photographs Division. Used with permission.

\section{THE MUTINY}

The mutiny occurred a week into the voyage, and about I 30 miles northeast of the Hole in the Wall. The captain, believing that he was closer to Abaco than he thought, ordered the brig to heave to for the night. All was calm, quiet, and dark; the rest of the crew and passengers were asleep. Gifford and three other mariners were on first watch. Washington had illicitly positioned himself in the women's hold. The women were silent. At about 9 o'clock, Morris approached the mate. Seeming to betray his co-conspirator, he reported that "one of the men had gone aft among the women". Gifford went back to wake the overseer, Merritt. The two of them returned, Merritt bringing a match and a lamp. Gifford stopped at the hatchway while Merritt descended into the darkness of the hold, and struck his match to light the lamp. When lit, it revealed Washington, who was standing behind him. Startled, Merritt said, "You are the last man on the brig I expected to find here". Washington replied, "Yes sir, it is me", and immediately leapt towards the ladder saying, "I'm going up, I cannot stay here."

Washington overpowered both men but Gifford stumbled to the deck as Washington emerged from the hold. Morris, who was still standing nearby, drew a pistol. He fired at Gifford, the ball grazing the back of his 
head. Washington ran towards the men's quarters in the forward part of the hold shouting directions, in order to signal that the uprising had begun. "We have begun, and must go through; rush boys aft, and we have them." It was vital that he stirred the slaves above and below into action either by fear or fury, and he yelled into the hold, "Come up, every damned one of you; if you don't and lend a hand, I will kill you and throw you overboard."

A group of waiting rebels came at Merritt with handspikes as he clambered up to the deck after Washington. He dodged a blow so that the weapon hit another rebel instead, allowing Merritt to break free and run down the ship towards the cabin. The rebels pursued both him and Gifford along the deck, and down the ladder into the corridor, Gifford shouting the alarm, "There's been a mutiny on deck, I've been shot." Other rebels quickly surrounded the entrance and the skylights on the quarterdeck above. As the rebels crowded down into the corridor, Hewell, one of the other passengers, grabbed a musket, and came out to confront the slaves. Faced with the firearm, the rebels retreated. Hewell followed them back up the ladder, and tried to defend the cabin. He fired the gun but it contained no shot. One of the rebels pulled it from him, so he grabbed a handspike, brandishing it in the dark. Not being able to see clearly, the rebels retreated further, momentarily thinking it to be another musket. ${ }^{7}$

During the moments that Hewell held back the rebels, Captain Ensor, armed with a bowie knife, rushed out through the forecastle further to rouse the crew members. A vicious fight began between the rebels and sailors, both groups armed with clubs, knives, and sticks. Ensor was felled in the starboard scuppers where the rebels repeatedly clubbed and stabbed him, yelling, "Kill the son-of-a-bitch, kill him."” Ben Blacksmith grabbed Ensor's bowie knife lying on the deck, and went for Hewell who, despite multiple wounds, was still fighting. Blacksmith stabbed him in the chest. Mortally wounded, Hewell got himself back down the ladder, and into Theophilus McCargo's berth, where he bled to death. His mutilated body was later thrown overboard on the orders of Washington, Blacksmith, and Morris. Severely wounded, Ensor crawled away from the melee and, with nowhere else to hide, struggled up the main shroud and secreted himself in the maintop.

With vicious fighting going on above, and all exits guarded, Merritt realized that he was trapped below decks. He tried to hide under the bedclothes while two of the women cabin servants sat on him but, terrified, they soon moved away. Two of the rebels burst into the room, one shouting,

6. "Protest", New Orleans Advertiser, 8 December I 84 I.

7. "Deposition of William H. Merritt", 9 November I 84 I, $P P$, I 843 , [485], p. I48.

8. "Deposition of Zephaniah C. Gifford", 9 November I84I, PP, I843, [485], p. I 49. 
"Kill the son-of-a-bitch, don't spare him; and kill every white person on board, don't spare one." Merritt had no idea who was dead by this time, and who was alive. Neither could the rebels be sure. Thinking quickly, with a knife to his neck, he told the insurgents that he had once been a ship's mate, and could navigate. ${ }^{\mathrm{I}}$

Gifford did not stay to fight long. The rebels attacked him with clubs and sticks, and one slashed through his clothes at his breast, with what he later identified as a large meat knife taken from the galley. ${ }^{\text {II }}$ Battered and terrified, he climbed the rigging into the darkness of the maintop. Once there, he found the severely wounded captain virtually unconscious, and, as the ship was pitching about violently, he tied the captain so that he would not fall, and then lay there listening as the rebels shouted to each other in the dark as they searched about for the ship's captain and mate.

The success of the revolt had depended on unleashing the full fury of the insurgents, but Gifford heard shouted orders revealing efforts to direct and limit the violence. While Merritt was hiding under his bed sheets, he heard shouts amid the chaos of, "Don't hurt the steward, don't hurt Jacob, or Mrs. Ensor." ${ }^{2}$ Jacob Leitner hid in his berth until he could not bear it any longer, and came up on deck to meet what he thought was his certain death. Morris, fully committed to maintaining the momentum of the revolt, ran out of the cabin at him shouting, "Kill every God damn white person on board the vessel, and if none else will, I will!" Leitner brought him up short by confronting him, "Will you kill me, Morris?" Morris stopped in his tracks, and assured him that he would not but demanded that he go down into the after hatch out of harm's way. ${ }^{13}$

The incident signals the ways in which the necessity of exacting the violence necessary to take the ship might easily have tipped into an indiscriminate and revengeful blood lust with potentially catastrophic consequences. Morris's sparing of Leitner also demonstrates that events were shaped by complicated relations between black and white, crew and enslaved. When rebels set to kill Jacques Lacombe, Washington warned them off, shouting that he was French, and could not speak English. This might not have been the only reason. Lacombe had remained steadfastly at the wheel throughout the battle. He may have done so through fear, or because he was unwilling to take sides.

Searching for ship's officers, the rebels entered the staterooms, and found the captain's wife, the children, and the steward, all of whom they

9. "Protest".

I0. "Deposition of William H. Merritt", 9 November I84I, pp. I4I-I42.

I I. Merritt M. Robinson, Reports of the Cases Argued and Determined in the Supreme Court of

Louisiana (New Orleans, LA, I845), X, p. 207.

I2. Ibid., p. I 42 .

I3. "Deposition of Jacob Leitner", $P P$, I $843,[485]$, p. I43. 


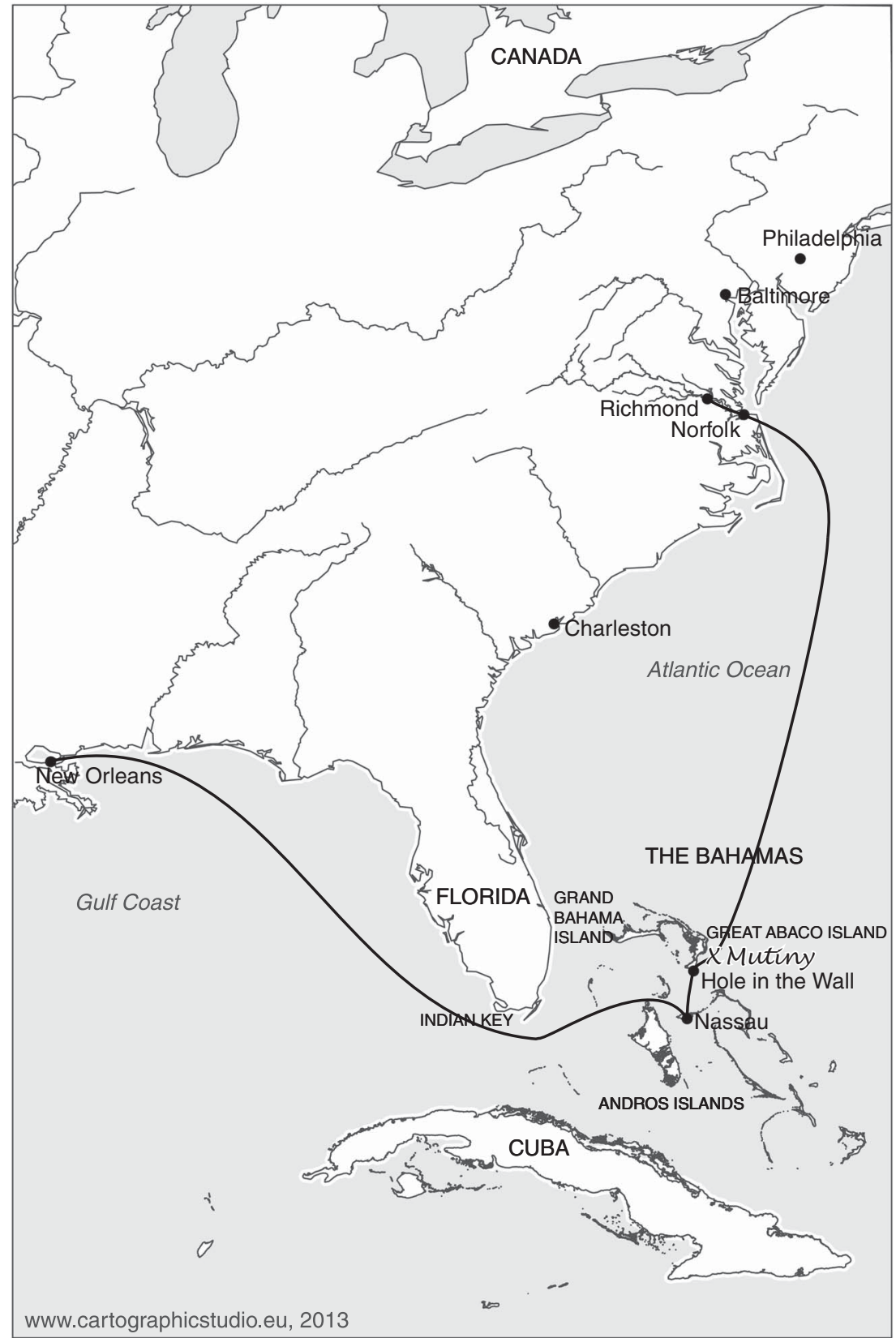

Figure 2. Map showing the route of the slave ship, the Creole, in November, I84I. 
secured in the hold. They discovered Stevens, the second mate, hiding in his cabin. The rebels burst in on him, one firing a musket. They chased him up onto the deck and attacked him with a piece of flagstaff, and knives. Wounded, Stevens scrambled up the fore shrouds on to the foreroyal yard, and stayed there. The three senior ship's officers were now aloft, and out of sight.

By about I am, the rebels felt confident enough to acknowledge that the ship was theirs. In a symbolic celebratory performance of upturned hierarchies, they called Leitner, the steward's mate, to the cabin, where he served them apples and bread and the officers' brandy. Leitner was clearly not regarded as an enemy. When one of the rebels took his watch, it was returned when it was realized that it did not belong to the captain. The rebels rifled the personal trunks, donned new clothes, and pulled the officers' stockings over their own. The search was not one of merely joyous subversion however. They were also looking for further weapons to secure their position. Apart from the officers who were aloft, and of whom they were still unaware, the upper deck was, for that moment, theirs. Determined to occupy previously forbidden space, as many who could fit in it slept in the cabin. ${ }^{14}$

The discovery of the ship's officers in the rigging at dawn revealed that tensions remained high, and the chain of command not entirely settled. The rebels were not in agreement about whether the officers should be killed. Amongst the crew, there was confusion about whose orders had precedence. Gifford, once returned to the deck, complained, "Some say make sail, and others say not, who shall I obey?". Stevens descended reluctantly, which infuriated some rebels who threatened to pitch him overboard. Gifford told them that Ensor was aloft and seriously wounded. At this point, Washington asserted his leadership, making it clear that he did not want any more killing. He ordered that Ensor be lowered to the deck, and then secured in the hold with his family after his wounds had been dressed. Nevertheless, Morris and Blacksmith kept threatening Stevens the next day, and that evening someone took a potshot at him as he walked along the quarterdeck in the dark, the bullet whistling past his head. ${ }^{\text {Is }}$ It was the last shot of the mutiny.

\section{BACKGROUND TO THE CREOLE REVOLT}

The Creole rebels achieved their extraordinary success because, as Eugene Genovese noted with more general reference to shipboard revolts, "the appearance of favorable conditions and a genuine chance of success could

14. Ibid., pp. I43-144.

I5. "Deposition of Lucius Stevens", Nassau, Io November I84I, PP, I843, [485], p. I40. 
trigger bold action". ${ }^{16}$ The rising was possible, in part, because of the lax conditions aboard the Creole. As Marcus Rediker has argued, transatlantic slave ships were vicious machines dedicated to the violent production of slaves, ruthlessly recalibrating African lives and bodies into human commodities as they plied the Middle Passage. ${ }^{17}$ The coastwise slaving vessels were not engaged in the production of slaves so much as transporting human beings understood by American traffickers to have already been "made" into slaves. It seems clear that slavers had grown complacent about the possible resistance of their human cargoes. They mixed them with other sundry merchandise, from bricks to tobacco, and from millstones to seeds. Why else did the Creole carry a slave trader's young family members? Why else was there only one musket between them all? Why else were none of the 135 African Americans either chained or restrained?

Allowing the captives a certain amount of mobility aboard may have been designed to prevent the build-up of tension, but the policy thereby enabled the captives to learn the layout of the ship, identify and collect together weapons - the meat knife from the galley, handspikes, "left forward by the windlass, where they could be picked up by anybody" whisper, plan, and organize themselves. ${ }^{18}$ It does not appear that the hatches were secure by 9 o'clock on the night of the rising. Washington had managed to leave one hold and enter the other without drawing any attention to himself, while no issue was made about Morris and several other slaves remaining on deck in the dark. As the captives had not even been searched when they were boarded, they may also have smuggled weapons on board. ${ }^{19}$

This last fact is significant for it highlights the fact that the idea of mutiny preceded embarkation. While practical details might have been worked out covertly during the first week at sea, a core commitment had already been formed on shore with the goal of taking the ship. The leaders of the rising, Washington, Ruffin, Morris, and Blacksmith, had been sold into the slave trade from different parts of the north, and would not have known each other until they met in the stinking slave pens. Washington is the only one of the Creole mutineers about whom there exists biographical detail, although it is probable that the other three men had prior contact with, or knowledge of, runaways and abolitionists. It would have been while awaiting their transportation that the Creole rebels first formed their alliances, told their stories, shared information, and forged a bond of trust that they then carried on to the slaver.

16. Eugene D. Genovese, From Rebellion to Revolution: Afro-American Slave Revolts in the Making of the Modern World (Baton Rouge, LA, I992), p. 6.

17. Marcus Rediker, The Slave Ship: A Human History (London, 2007), pp. 4I-45.

I8. Robinson, Reports of the Cases, p. 336.

19. Ibid., pp. 217-218. 
Washington's fragmented story not only confirms an intense desire for freedom but also that, as a fugitive slave, he had moved covertly through radical abolitionist networks of communication and asylum prior to his recapture. Here, he had listened to the arguments for violent resistance, and, even more specifically, he had been presented with a heroic figure and a model for successful action. Washington was born a slave in Virginia. In late 1839 he had fled to Canada using the Underground Railroad. In early I 84I, against the advice of well-known abolitionist activists, Hiram Wilson, Henry Garnet, and Robert Purvis, he travelled back down the railroad to Virginia in search of his wife. He returned via Philadelphia where he stayed with Purvis, who had previously helped him reach Canada.

Fifty years later Purvis recalled Washington's surprising visit. He had arrived on the same day that Purvis took possession of a striking portrait entitled, "Sinque, the Hero of the Amistad", painted by the abolitionist artist Nathaniel Joceylyn. Washington was "intensely interested" in the picture and in the story of the famous rebellion. Purvis recalled that " $[\mathrm{h}] \mathrm{e}$ drank in every word, and greatly admired the hero's courage and intelligence". ${ }^{20}$ Washington was recaptured in Virginia in early I $84 \mathrm{I}$, and sold to Thomas McCargo. Burning with rage, and holed up in the Norfolk slave pen, the recent memory of Cinqués portrait must have galvanized Washington, while relaying the story of the Amistad to his fellow captives surely provided inspiration and vital coordinates for calculating the possibility of another shipboard rebellion.

Slave pens existed all around the harbours of the eastern seaboard for holding captives while traders acquired enough human property to fill a hold. Captives were also trans-shipped between vessels while they were at anchor. This enabled conspiracies to travel from shore to ship, and from ship to ship. At least fifteen other captives took part in the Creole revolt. It is not clear whether the four met them on shore, or recruited them to the cause once aboard. Nevertheless, what is clear is that planned mutiny had already dramatically breached the division between shipboard and the Norfolk shoreside on previous occasions. If stories of the Amistad rebellion were circulating in I84 I, they would have mixed with those of earlier slave-ship revolts inspired by the revolution in, and proximity of, Saint-Domingue.

In I 826, rebels took the slave ship Decatur after it had departed from Baltimore and ordered that it be sailed to Saint-Domingue. The mutiny was quelled before it reached the island. ${ }^{21}$ Perhaps inspired by the attempt, another revolt occurred on the Lafayette, which departed from Norfolk harbour in I829. As with the Creole, reports suggest the

20. Philadelphia Inquirer, 26 December I 889 .

2I. For reports of the mutiny aboard the Decatur see the Essex Register, Salem, MA, 22 May I826, p. 3; City Gazette and Commercial, Charleston, South Carolina, 26 May I826, p. 2; Alexandria Gazette, Alexandria, Virginia, 22 May i 826, p. 2. 
complacency of the captain and crew in the face of the potential for an uprising. The large slaver also carried extra cargo, and other white passengers. The 197 male and female slaves had been separated by using a ship's boat stowed bottom up and athwart the ship as a bulkhead. It could, as Solomon Northup later affirmed, be used to spark an insurrection. The ship's crew managed to overpower the rebels during a vicious fight. Later, under interrogation, twenty-five men, deemed to be the leaders of the affray, revealed the magnitude of the plot.

The rising had been organized amongst the group of slaves previously held aboard another slaver, the Ajax, while it lay in Norfolk harbour. Those who were transferred to the Lafayette had taken the plan with them. The Ajax had sailed a few days after the Lafayette, and it was later confirmed that a planned revolt on the Ajax had reputedly been betrayed before it could be staged. The Lafayette rebels undercut whatever reassurance might have been supplied to the enemy by the revelation of fragile solidarities. They told their interrogators that the slaver, the Transport, following on behind the Ajax, was also carrying captives who were committed to the same plan. ${ }^{22}$

Even though these insurrections were unsuccessful, the prospect of rolling waves of shipboard mutinies, each one copying the next, exacerbated the already well-established alarm amongst southern slave owners. ${ }^{23}$ The fact that the militants, like those aboard the Decatur, had "confessed that their object was to slay the whites and run the vessel to St Domingo" simply confirmed for them that slave revolt haunted them at every turn. The New Orleans Courier, reflecting on the Lafayette conspiracy, glossed its incendiary nature by claiming that the revolts were the result of moral degeneracy rather than political impetus. The editors argued that they were "among many of the evil consequences attendant upon the system followed by our northern neighbors of sending the most worthless and abandoned portion of their slave population to this place". ${ }^{24}$

The geographical and historical proximity of Saint-Domingue exerted an extraordinarily powerful motivating force on both enslaved African Americans, immobilized on the plantations, and on those funnelled into overland and maritime slaving routes. ${ }^{25}$ In I84I, however, the Creole rebels chose not to steer for the new republic. By this time, another possible maritime route to freedom had more immediate valency, of which the rebels also had prior knowledge and which determined the next stage of the mutiny.

22. New Orleans Courier, I4 December I 829.

23. Rothman, Slave Country, pp. 165-216.

24. New Orleans Courier, I4 December I 829.

25. Alfred N. Hunt, Haiti's Influence on Antebellum America: Slumbering Volcano in the Caribbean (Baton Rouge, LA, I988), pp. 107-188. 


\section{VOYAGE TO THE BAHAMAS}

After gaining final control of the Creole, Washington took Merritt into one of the staterooms and - perhaps remembering Cinqué - told him that they wanted to sail for Liberia. Merritt replied that the ship was equipped with neither provisions nor water to make a transatlantic crossing. Then Blacksmith and several others said, "they wanted to go to the British islands; they did not want to go anywhere else but where Mr Lumpkin's Negroes went last year". They were referring to the slave ship Hermosa, which had been wrecked off Abaco the year before. They knew that having been rescued by Bahamian wreckers and taken into Nassau, "Mr. Lumpkin's Negroes" had been freed by the British colonials. ${ }^{26}$

The Hermosa was not an isolated case, even if it was the most recent. As the prospect of British emancipation loomed across the West Indies, a set of shipwrecks off the Bahamian islands had resulted in the loss of hundreds of thousands of dollars for American traffickers, and freedom for several hundred African-American slaves. American slaveholders and their government had been serially scandalized by what they saw as tyrannical British interference in property rights, and sought compensation. The rebels' demand to sail to the Bahamas shows that enslaved African Americans knew the details of these earlier shipwrecks, or near shipwrecks, and came to view the Bahamas, less than 200 miles from the coast of Florida, as a vital coordinate in their contemporary geopolitical map of freedom. ${ }^{27}$ Moreover, unlike the rebels aboard the Amistad, the new masters of the Creole also had a smattering of vital maritime knowledge that would help them to get there.

Whether he had been employed at sea previously is not clear, but Pompey Garrison, one of the rebels, had apparently sailed to New Orleans before, and knew the route. George Cortlock and Doc Ruffin "knew the letters of the compass". Once Merritt had ordered his crew to set sail for Nassau, the rebel leaders took turns to watch the compass, forbidding Merritt and Gifford, on pain of death, from speaking to each other, or from taking their reckonings in writing in case they were secretly communicating. It could not be taken for granted that the crew, or the rest of the enslaved, or even the rebel leaders, would submit peacefully to the plan. The rebel leaders took stations around the ship in order to maintain their control. Morris intimated that all was not fully agreed amongst them when he was asked whether the intention was to kill all the sailors. $\mathrm{He}$ replied, "No: I expect we shall rise again among ourselves, but the white

26. Philip Troutman, "Grapevine in the Slave Market: African American Geopolitical Literacy and the $184 \mathrm{I}$ Creole Revolt", in Walter Johnson (ed.), The Chattel Principle: Internal Slave Trades in the Americas (New Haven, CT, 2004), pp. 203-233.

27. Ibid., p. 209. 


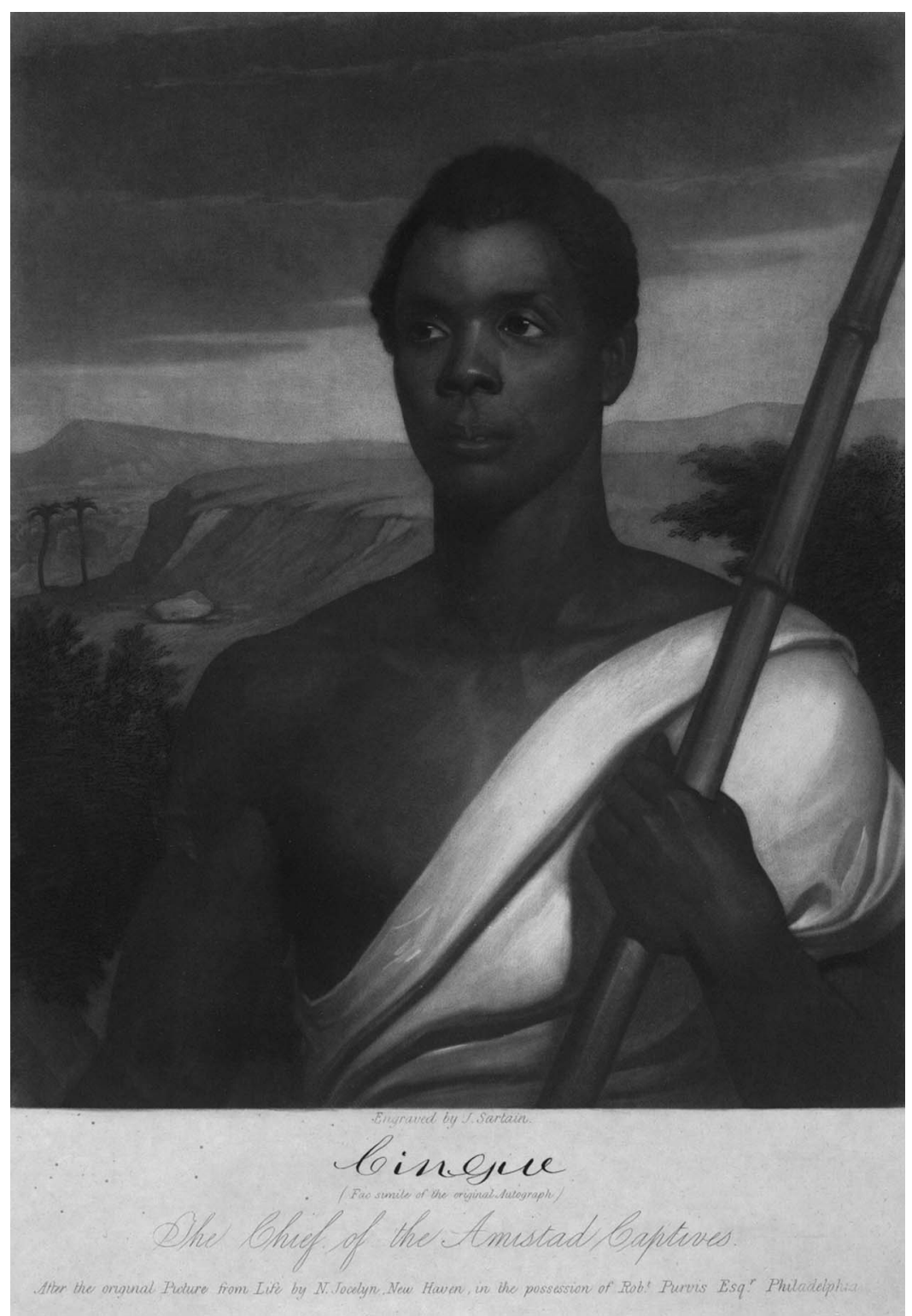

Figure 3. Madison Washington saw this portrait of Cinqué, leader of the Amistad mutiny, at the home of Robert Purvis with whom he stayed in I84I prior to his recapture and the mutiny aboard the Creole.

Yale University Art Gallery 
people shall not be hurt." ${ }^{28}$ No such divisions occurred, however, the rebels ensuring that their authority over both captives and crew remained secure until they reached Nassau.

As the Creole approached the harbour on the morning of 9 November, a pilot boat came out to meet the brig. The rebels jettisoned their weapons into the sea, and, leaving their watch positions, began to mix amongst the captives. Despite the fact that British post-emancipation law recognized African Americans as free persons, at this moment there could be no certainty about how that law would be translated once the colonial authorities knew about the conditions under which this ship had arrived. Merritt recalled that "the other Negroes were laughing and looking on and appeared much animated as they would had there been no mutiny", although the rebels seemed anxious. ${ }^{29}$

If they were not quite ready to let their guard down, however, their first contact with local Bahamians set terms for an extraordinary set of solidarities and identifications that would develop and spread over the coming days. As he boarded, one of the pilot boat's black crew told the African Americans that "he came out from Charleston, and that he got free by coming out there in that way". He may well have been captive aboard the Enconium, another American slaver that had been shipwrecked off Abaco eight years earlier. The meeting produced jubilation on the Creole. One white witness noted that the African Americans "kissed the negroes that came on board and said, you are my brothers, \&c. The negroes of the Creole laughed, and appeared much rejoiced, particularly those who heard the negro say, that he had got free in that way". ${ }^{\circ}$

For obvious reasons, Gifford did not board the pilot boat. He went on shore in the quarantine boat to inform the American Consul, Bacon, of the mutiny. Bacon immediately requested that the Governor send a guard on board until it was clear what should happen next. The Governor acceded by sending twenty-four Second West India Regiment troops armed with muskets, bayonets fixed. The soldiers were Africans to a man, with the exception of their captain. Like many of the inhabitants of Nassau, the soldiers had been kidnapped from the coasts of West Africa, and had endured the Middle Passage aboard illegally operating slaving vessels. Intercepted by the British, these Africans were rescued under the terms of the Abolition Acts that funnelled them, involuntarily, into the British Army, or, prior to emancipation, ensured they were "apprenticed" for a maximum of fourteen years.

28. "Protest".

29. Johnson, "White Lies", p. 244.

30. McCargo v. New Orleans Insurance Company, printed testimony of Jacob Leidner, pp. I-2, Dockett 4409, New Orleans Public Library. 
In the years between the passing of the Acts and I84I, at least two dozen ships landed over 6,000 rescued Africans in the Bahamas. ${ }^{3 \mathrm{I}}$ Those who were not recruited into the military were initially bonded in a variety of situations across the mixed economy, including in plantation agriculture, maritime occupations such as fishing, sponging, wrecking, and salt-raking, and in a variety of skilled and semi-skilled trades and shopkeeping in Nassau. The African troops boarded the Creole, and with the aid of the crew identified the leaders of the mutiny, Washington, Ruffin, Morris, and Blacksmith, and tied them down in a long boat. Over the next few days, the Consul and the British Attorney General travelled out to the vessel to begin deposing the Creole's officers and crew.

The troops secured the rebel leaders but ignored the order not to communicate with their charges and were, apparently, in continual and familiar and even intimate contact with them throughout the week. The Americans were alarmed at the resulting subversion of racial and social hierarchies on board, while Merritt felt that the soldiers purposefully undermined his position as a senior ship's officer. When he raised the issue with the commanding officer, "who he found conversing with a coloured female with his cloak around her", he was, Merritt reported, simply brushed off. ${ }^{32}$ Even more shockingly, the commanding officer apparently

[...] told Mary, one of the slaves owned by Thomas McCargo, in presence of many of the other slaves, how foolish they were, that they had not when they rose killed all the whites on board, and run the vessel ashore, and then they would all have been free, and there would have been no more trouble about it. ${ }^{33}$

Meanwhile, Consul Bacon knew what had happened in the cases of the shipwrecked Comet and the Enconium, and had been Consul when "Mr. Lumpkin's Negroes" had been freed from the Hermosa the year before. He was determined that the British would not embarrass him again. He approached Captain Woodside, Master of the Congress, another American vessel docked in the harbour and, together with the Creole's officers, they devised a plot to retake the ship with the aid of Woodside's crew. They planned to sail it to Indian Key, where there was an American man-of-war permanently based - as a result, amongst other things, of the Seminole Wars that were raging in Florida - which could facilitate their onward journey to New Orleans. If the ship was to be reclaimed by force, however, the crew of the Creole required rearming as the mutineers had

31. Rosanne Adderley, "New Negroes from Africa": Slave Trade Abolition and Free African Settlement in the Nineteenth-Century Caribbean (Indianapolis, IN, 2006), p. I०.

32. "Deposition of William H. Merritt", Nassau, Bahamas, I 3 November I 84 I, PP, I843, [485], p. I32.

33. "Protest". 
jettisoned the few weapons that were originally aboard. Bacon and Gifford undertook to go into town and purchase new guns.

Their mission revealed that news about the mutiny had already spread like wildfire around Nassau. It seemed that everyone knew that there were American slaves being held aboard the Creole. Crowds began to gather around the harbour front. If the Bahamian mariners and the African troops were in solidarity with the rebels' cause, it transpired that so too were Nassau's weapons dealers. They all refused to sell to the Americans. It also seemed that everyone already knew exactly who Gifford was, and as he walked down the street he was subjected to jeers and insults from both black and white residents. He reported that he heard them say, "There goes one of the damned pirates and slavers". ${ }^{34}$ Defeated, Gifford and Bacon decided to scrape together what spare guns they could procure from two other American vessels. Their preferred plan was to wait until the nineteen rebels had been taken from the Creole. Clearly, it was worth the loss of the most dangerous slaves in order to secure the rest for the New Orleans markets. Thus, they waited as the endless depositions were accumulated, and the tension mounted in Nassau, Woodside, with the Consul checking with the Creole's crew day by day as to the appropriate moment to strike. While British officials appeared to be in no hurry to act, however, it began to look as if local Bahamians might.

\section{LOCAL SOLIDARITY AND THE THREAT OF REVOLT}

The pattern of social protest that followed drew directly on the experience of previous struggles. Many Afro-Bahamians who acted would have remembered the day the slaves were liberated from the Hermosa only the previous year. Some might have remembered the shipwrecked Comet or the Enconium in I83 I and I 833. Others, like the black mariner, may even "have got free in that way". In each prior case, Bahamians had been key in minimizing British vacillation about freeing enslaved Americans, and blocking interference by American traders, resident slaveholders, or illegal traffickers. In each prior case, British colonials had acted on a clause in their anti-slave trade legislation that had determined that captives who survived shipwrecks in the West Indies were freed, but it was the local community who created the conditions in which it would have been extremely difficult for the British to have acted otherwise. To this extent the Creole mutineers sailed into, and were embraced by, another sphere of the wider tradition of black Atlantic resistance and cooperation.

When the Comet and the Enconium foundered off Abaco in the early I830s, it was the same group of Bahamian wreckers who rescued each 
vessel's captain, crew, and slaves, insisting that they travel to Nassau. Bahamian "rackers" had long scouted the out islands for the valuable salvage thrown up as European and American vessels foundered on the reefs as they entered and exited the Caribbean. Made up of poor whites, escaped slaves, and their descendants, and later liberated Africans, the wreckers had a reputation for being little other than smugglers and pirates. ${ }^{35}$ Yet, it was wreckers that helped ferry black Seminoles and runaway slaves, escaping extermination in Florida, to the Andros Islands during the $1820 .^{36}$

The intervention by the wreckers meant that the captives did not arrive at Nassau under an American flag. Once arrived, the captain of the Comet was served with a writ which stated that the slaves were to be seized and freed. ${ }^{37}$ All but three (who refused to disembark) of the sixty-one captives who had been aboard the Enconium were also landed and legally freed. They were then fed and accommodated in the army barracks by liberated African soldiers. ${ }^{38}$

Both cases infuriated the southern press, the American government, and the Bahamian assembly. The day before the authorities seized the captives from the Comet, the assembly sent a hysterical and unanimously signed letter of protest to the colony's governor. Resurrecting earlier fears about the arrival of the liberated Africans and echoing southern planter fear and prejudice, they wrote:

The sudden irruption [...] of this large body of strange Creole slaves, also combining as the American negroes generally do the Intelligence and cunning of the lower order of Freemen, with the characteristic want of thought and foresight almost inseparable from a state of Slavery, the profligate habits, the vices, the crimes, which have notoriously been the frequent occasion of the deportation of Slaves, from the Atlantic States to the Western settlements of North America would be but too justly calculated to inspire fears in this quarter of the most alarming character. ${ }^{39}$

Despite their remonstrations, six months after the passing of the British Abolition Act, another seventy-eight enslaved Americans found freedom in nearby Bermuda. They had been aboard the slaver, Enterprize, en route

35. Virgil Henry Storr, Enterprising Slaves \& Master Pirates: Understanding Economic Life in the Bahamas (New York, 2004), pp. 47-48.

36. Rosalyn Howard, "The 'Wild Indians' of Andros Island: Black Seminole Legacy in the Bahamas", Journal of Black Studies, 37 (2006), pp. 275-298; Irvin D.S. Winsboro and Joe Knetsch, "Florida Slaves, the 'Saltwater Railroad' to the Bahamas, and Anglo-American Diplomacy", Journal of Southern History, 79 (2013), pp. 5 I-78.

37. National Archives, London [hereafter NA], $\mathrm{CO}_{23} / 92$.

38. The Enconium was sailing from Charleston to New Orleans carrying sixty-four captives, rice, naval stores, millstones, and sundry merchandise. See "Protest" by Captain Staples of the Enconium, n.d., NA, CO 23/92.

39. "Bahamas House of Assembly", I4 January i 83 I, NA CO 23/92. 
from Alexandria to Charleston. ${ }^{40}$ Damaged in a storm, the brig was forced into Hamilton Harbour, but once repairs were completed local customs officials refused to give clearance for the vessel until a legal ruling had been made regarding the status of the captives on board.

Over several days, word spread across the island that American slaves, most of them children, had been discovered in the vessel's hold (they were not listed on the ship's manifest). Again, the planter class expressed their concern about the consequences of releasing enslaved Americans in the colony. ${ }^{4 \mathrm{I}}$ The newly apprenticed and free black Bermudan population, on the other hand, rapidly mobilized amongst themselves. They took immediate action when the captain, Elliott, made ready to sail. Crowds gathered as an Afro-Bermudan named Tucker, leader of a newly instituted Young Men's Friendly Lodge - one of the many post-emancipation collectives founded by the free blacks to provide mutual welfare, support, and to campaign for political and labour rights - obtained a writ of habeus corpus against Elliott. ${ }^{42}$ Elliott watched helplessly as the captives disembarked to the cheers of an immense crowd that surged along with them, and then packed the courthouse late into the night determined to see justice done..$^{43}$

All but one woman and her five children elected to claim their liberty. The crowd immediately began a collection amongst themselves to provide for the ex-slaves' needs. The members of the Friendly Institution also arranged for their temporary accommodation by securing an empty house in the town, "and the next day by the interposition of their Society nearly all [...] obtained places in different parts of the Colony". ${ }^{44}$ As these examples demonstrate, maritime and land-based traditions from below of mutual aid and local anti-slavery activism - played a crucial part in successive liberations of American slaves in the Bahamas and Bermuda well before the Creole's triumphant arrival in Nassau. The story of the Hermosa, which proved to be so pivotal for the Creole rebels, further bolstered these traditions.

The Hermosa foundered off Abaco on 19 October i 840. Also sailing from Richmond for New Orleans, the slaver was carrying a cargo of cotton goods, tobacco, and forty-eight slaves. Again, Bahamian wreckers

40. Governor of Bermuda to Earl of Aberdeen, 28 February i 835 , NA, CO 37/96. The Enterprise carried no mounted guns, and, together with 3 paying passengers, was loaded with a cargo of 40,000 bricks, 6 hogsheads of tobacco, a large supply of seeds, and 78 captives.

4I. Ibid.

42. Howard Johnson, "Friendly Societies in the Bahamas I834-1910", Slavery \& Abolition, I 2:3 (I99I), pp. I 83-199. Although Johnson focuses his study on the Bahamas, he notes at the outset that, "Until the development of viable trade unions in the late 1930s, the Friendly Society remained the characteristic working-class organisation in many areas of the British Caribbean", p. 183 .

43. Nellie Musson, Mind the Onion Seed (Nashville, TN, 1979), pp. 65-67.

44. NA, CO 37/96. 
rescued all who were aboard, salvaged the cargo, and sailed for Green Turtle Key. While the captain, Chattin, was ashore arguing with the customs officers, stipendiary magistrates and a priest boarded the wreckers to advise the forty-eight that they were free.

Chattin sought support from Consul Bacon once they arrived in Nassau, but the captives were disembarked before they could complete their protest. At the magistrate's office, Chattin reported that he could not hear what was being said because "the mob was so great", and that he and Bacon were "forced out of doors". The British West India Corps, heavily armed, later prevented him from communicating with the African Americans as they spent their first night of freedom housed in Crown buildings. $\mathrm{He}$ made another attempt to claim them the next morning, but the entire group had already disappeared into the Nassau market crowds. ${ }^{45}$

Even if it was inevitable that, in each case, colonial officials (without the support of the planter class) would have legally pronounced the enslaved Americans free, the local community's identification with the captives forced the issue in a moment of danger. In the case of the Enterprize and the Hermosa, it was the direct action of the crowd that prevented the ships' masters from absconding. By insisting on bearing witness, and in huge numbers, they ensured that the captives were recognized as full rightsbearing subjects before the law, and offered their support thereafter. They were determined that the same should happen for those on the Creole.

The Creole had been lying in the harbour for four days when the tension intensified dramatically. Crowds again lined the waterfront, and surrounding balconies were packed with men and women with spyglasses trained on the Creole. Rumours that the "blacks of the island" were planning forcibly to rescue the captives that day were rippling through the town. It quickly became clear to Bacon that the local community was once again mobilizing. He was accosted repeatedly by "respectable" whites, one of whom told him that their servants had been meeting at night, and planned to assist in the liberation of the slaves that day. Another gestured towards the harbour, informing the Consul that the launch heading out towards the Creole belonged to him, and had been commandeered, and "that the slaves were to be liberated by the blacks by means of boats". ${ }^{6}$ By the time Bacon arrived at the brig, it looked to him that the rescue attempt had begun. The crowd had taken to the water. The Creole was completely surrounded by at least fifty small boats, and a large sloop, packed with Bahamians armed with clubs, had been towed out and anchored near the brig. The men aboard the sloop were distributing the

45. "Further Protest and Deposition of the Master of the Hermosa", New Orleans, PP, I843, [485], p. 201.

46. Robinson, Reports of the Cases, p. 227. 
clubs amongst the smaller boats. Bacon was told that one attempt had already been made to board the Creole.

Pinder, the Police Magistrate, concerned about public order, decided he could do nothing about the bristling "mosquito fleet", and so went instead to where the crowds were assembled. ${ }^{47}$ Bacon also decided it would be unwise to board the vessel, given its now highly seditious context. $\mathrm{He}$ returned to his office to warn the Governor of the volatile situation in the harbour, and to request support. Gifford, frightened for the safety of his crew and of losing his property, was waiting for him when he arrived.

Having sent his letter, Bacon must have realized that there was limited time before the Governor's forces would act. In any case, it looked as if the Bahamians were about to overwhelm the ship. If it was going to stay in American hands, if indeed it still was, then the plan that he had concocted with Woodside and the officers of the Creole to take the ship by force had to be enacted immediately. Bacon ordered Creasy, the mate of the Congress, to take four sailors, and the few muskets and cutlasses that they had gleaned, and row out to the Creole. This could no longer be a covert operation; it was broad daylight, and there were at least 2,000 people watching. According to the later "Protest" (interestingly, no individual deponent mentioned this incident at the time, except Woodside), "a negro in a boat" spotted them loading the boat, the arms concealed in an American flag, and following them across the harbour "gave the alarm to the British officer in command on board". The crowd watched, "the excitement increasing", as Creasy's tiny army approached the brig, only to be told by the British officer on board that they would be fired on if they came too near. ${ }^{48}$ With a line of twenty-four West India muskets, with fixed bayonets, trained down on them, and surrounded by masses of armed fishermen, stevedores, and droughers, they had no option but to withdraw.

Aboard the Creole, the Americans became increasingly anxious as the fleet accumulated around them. As the confusion intensified, the boundaries of the vessel, and between the parties aboard, were further breached as first Woodside boarded, and then two clergymen who, ignoring the Americans, engaged in "familiar conversation with the slaves", seemingly readying them for their departure. The women began "patting their bonnets", and packing up their belongings. ${ }^{49}$ Stevens recalled that the black pilot urgently called up from the sloop, "Come get through with your business on board, we want to commence ours". Woodside disembarked to tell the Consul what he already knew, that the brig was "literally surrounded with boats full of black people armed with clubs". ${ }^{\circ}$

49. "Deposition of William Woodside", i 3 November I84I, PP, I843, [485], p. I 3 I.

50. "Deposition of Zephaniah C. Gifford", 9 November I 84 I, p. I33. 
Back on shore, Bacon was summoned to a rapidly convened council session where he had a testy discussion with the Governor. The Governor knew about the American plot, and that the situation in the harbour was now on a knife-edge. He informed Bacon that he was finally sending the Attorney General out to the Creole to identify those implicated in the murder, remove the troops, and to oversee the landing of the rest of the party of slaves. There was nothing Bacon could do except rush back, and advise Gifford and Woodside to return to the Creole as fast as possible, and to do all they could to protest at the liberation of the slaves. It was all over an hour later.

The Attorney General's initial report offers a measured and procedural narrative of the subsequent events in which he reported that he successfully reasserted British authority over the amassed Bahamians by ordering them to throw their clubs overboard. (Later, in the insurance trials, he was to deny that "the boats were subject to his orders"). ${ }^{51}$ Boarding the Creole, he informed Washington and his eighteen compatriot rebels that they were charged with "mutiny and murder", and would be taken into custody by the troops to await word from London. He placated the Creole's officers and crew regarding their fear that the Bahamians would exact violent revenge, and then informed the rest of the assembled captives that, as far as the authorities were concerned, they were no longer subject to any restrictions on their movements. The news, he reported, gave them "great pleasure". Later, he added that he "called upon them to say what they would do", whereupon a "shout almost immediately rose from among the coloured persons [...] with one voice to express their determination to quit the vessel". ${ }^{2}$ He said that he then made a signal, and observed from a small boat as the captives crowded over the side of the ship into their waiting, and welcoming, ferries. ${ }^{53}$

Merritt, Gifford, and Stevens gave a more chaotic and contingent representation of events as they apparently struggled to maintain a hold over the slaves in the face of terrible intimidation by the Bahamians, and the interference of the British. Merritt reported that he strenuously tried to persuade the captives to stay aboard, while "white persons were telling the captives that they would probably be punished if they went to New Orleans". The depositions suggest that either the British officials were happy to exploit the Americans' anxiety, or that their own authority was less secure than it appeared to be. Merritt asked a magistrate what "all this meant, the boats and the launches being full of men armed with clubs". The magistrate told him that as "soon as the troops were removed, they

51. Robinson, Reports of the Cases, p. 25 I.

52. Ibid., p. 249.

53. "Report of G.C. Anderson, Attorney General of the Bahamas", I 3 November I84I, PP, I 843 , [485], pp. I29-I 30 . 
would probably come on board, when there would probably be bloodshed". The Americans also reported that only "some" Bahamians threw their arms overboard at the behest of the Attorney General, and that throughout the proceedings the troops were having difficulty keeping the Bahamians from repeatedly attempting to board the vessel. Merritt reported that he had asked for protection "as he feared that those in the launches and boats, when they came alongside, would commit some violence". ${ }^{4}$ Gifford reported his "serious fears", and the "agitation of the moment", in which he may, or may not, have said of the slaves, "Let them go". He could not recall. Others certainly did recall that he had done so. 55

Stevens was also fixated by the "threatening state of things". He stated that the men aboard the small vessels "showed fight" with their clubs, "swinging them about in a threatening manner, at the same time using insulting language". ${ }^{6}$ Later in the insurance trials, he noted that the Attorney General, after informing the slaves that they were "at liberty", turned around and "waived his handkerchief to the boats which surrounded the brig; as did the other magistrates", signalling them to approach. ${ }^{57}$ The fluttering of handkerchiefs, presumably white, by the highest representatives of colonial law, was an ambiguously laden sign. It was a signal that the slaves could be disembarked. But, if read as the universal referent for surrender, it might also point to the critical issue: that quite who was surrendering what, and to whom, had never been completely certain.

Stevens' testimony is redolent of the Americans' confusion as their world turned upside down for a second time. He recalled the enormous cheer that erupted around the harbour as the captives disembarked, and simultaneously the alien sight of black slaves being treated with decorous, and very British, propriety. He reported that he heard two magistrates say, as they assisted the departing women over the side of the brig, "Here ladies, this is a nice boat on purpose for ladies get in here" 58

It suited the slavers to construct a narrative that helped to secure their status as victimized patriots harassed by British imperial tyranny. Simultaneously, British authority required the veneer of colonial control throughout this last phase of the revolt. Both sets of narratives are compromised, however, by the collective action taken by the Bahamian crowd both on land and afloat during the last phase of the Creole's story. The justice-seeking "mosquito fleet" had been, at least in part, organized in advance, and drew on previous patterns of political action. It showed

54. "Deposition of William H. Merritt", I 3 November I 84I, pp. I32-I 33.

55. Robinson, Reports of the Cases, p. 254.

56. "Deposition of Lucius Stevens", i० November i 84I, p. I3 I.

57. Robinson, Reports of the Cases, p. 223.

58. "Deposition of Lucius Stevens", i० November i 84I, p. I 3 I. 
impatient restraint as the boats waited to ferry the captives to shore while the spectacle of their numbers, their noise, and the threat of violence that accompanied their presence helped to prevent the Americans from recapturing the ship, and forced the issue of the captives' release. To adapt E.P. Thompson's famous terms, the water-borne crowd had, as its "legitimising notion", the revolutionary right to freedom, while British colonial abolitionism signalled the "measure of licence afforded by the authorities" necessary for the assertion of those rights. ${ }^{59}$ The multiple and fractured recollections of the events recorded in the official archive gesture at what was unspeakable for both the Americans and the British: that things might have taken, and nearly had taken, a very different route.

The black pilot who had pressed so hard for the slaves' emancipation ensured that all the captives were safely ferried to shore, although he could not persuade Rachel Glover, a young girl named Mary, two other women, and one of their sons, to claim their freedom. They, like the unnamed woman and her five children on the Enterprize, chose rather to sail for New Orleans. Their decisions mark the complications that gender brought to the unforeseen prospect of Caribbean freedom. It is impossible to know exactly why the women did not disembark, but they may have been in search of husbands or children previously sold away to New Orleans. They may have had relationships with the Creole's crew members, or they may have been fearful of further exploitation if left legally free but vulnerable, and with children to care for, in a strange country. Of the rest, many took up a British offer of passage to Jamaica almost immediately. The British held the nineteen identified as "mutineers" for nearly six months but, in the end, the charge of piracy collapsed. Like the groups of African Americans previously freed from the wrecked vessels, Washington and his compatriots disappear into the Atlantic vortex at this point, leaving the imperial nations to squabble for years over the irreducibly liquid boundaries of the sea, so-called property rights in persons, and the fictions of "race" in the determination of universal freedom.

\section{CONCLUSION}

The revolt aboard the Creole has taken its place in the epic tradition of black anti-slavery revolts against white American colonial authorities. Madison Washington's leadership is repeatedly cited alongside that of Nat Turner, Denmark Vesey, and Gabriel Prosser. The story of the Creole reaches far beyond the boundaries of national history or memory, however,

59. E.P. Thompson, "The Moral Economy of the English Crowd in the Eighteenth Century", Past E Present, 50 (1971), pp. 76-136, 78. 
and beyond the singular brilliance of its leader. The enslaved Americans liberated themselves by staging a mutiny within a geopolitical context that breached land and sea in a myriad of imagined and material ways. Their extraordinary success is testimony to the circulation of radical struggle, the wider currents of political action, and the power of fugitive connections that together defined the collective nature of the revolutionary Atlantic. 